\title{
Effects of Assurance Mechanisms and Consumer Concerns on Online Purchase Decisions: An Empirical Study
}

\author{
Mohammadreza Mousavizadeh
}

Dan J. Kim ${ }^{*}$

Rui Chen 


\title{
Effects of Assurance Mechanisms and Consumer Concerns on Online Purchase Decisions: An Empirical Study
}

\author{
Abstract \\ Online purchases are constantly challenged by potential threats which include compromised vendors' \\ security and breaches of customer privacy. To mitigate these concerns, several information assurance \\ mechanisms (e.g., assurance statements and third-party certifications) have gained attention in practice. \\ Despite the wide deployment of assurance mechanisms, it remains largely unknown as to how online \\ consumers interpret these assurance mechanisms and how their concerns affect their purchase decisions. \\ Focusing on two information security assurance mechanisms (i.e., assurance statements and third-party \\ assurance seals services) and three focal concerns of online consumers (i.e., privacy, security, and product \\ and service concerns), this study investigates how security assurance mechanisms influence purchase \\ decisions through alleviating the three focal concerns. The empirical results of the study reveal the \\ relative strength and weakness of the two assurance mechanisms and also uncover the mediating roles of \\ the focal concerns between assurance mechanisms and online consumers' purchase intentions. Post-hoc \\ analysis further shows assurance seals supplement the effects of assurance statements on privacy concern \\ and product and service concern, which is also a new finding to the literature. Finally, results show that \\ concerns on security and privacy displace concern on product and service (a non-information security \\ concern), when effects of the three concerns are concurrently considered by consumers. The implications \\ of findings for both theory and practice are discussed.
}

Keywords: Security assurance mechanisms, assurance statements, third-party assurance seals, privacy concern, security concern, product and service concern. 


\section{Introduction}

In recent years, online shopping has become more popular than ever before. The latest analysis of the U.S. Census of Bureau reported the retail e-commerce sales for the second quarter of 2015 was $\$ 83.9$ billion - an increase of 4.2 percent from the previous quarter [1]. Worldwide, the total retail e-commerce sale is projected to rise to $\$ 2.489$ trillion in 2018 [2]. As an important online business model, Business-toConsumer (B2C) electronic commerce represents a major online transaction platform which appeals both buyers and sellers [3]. For sellers, the efficient use of time combined with the technological improvements drive them to develop digital storefronts for the provision of goods and services. For buyers, online shopping provides convenience, time and money savings, and hedonic values which promote consumers towards online purchases [4]. In fact, there is no constraint of time and space in B2C retailing that would convince both buyers and sellers choosing this channel [5].

While online shopping introduces a myriad of benefits, consumers may develop concerns and worries with regard to their online purchases. Prior studies have reported that online consumer's concerns play important roles in their purchasing decisions [6]. Miyazaki and Fernandez [6] identify three focal online concerns that hinder online consumers in their purchase decisions: product and service concerns, security concern, and privacy concern. Product and service concern refers to the fraudulent behavior of the online retailers in association with product and service. Examples are such as delivery of defective product and unsatisfactory service after sales. Transaction security concern is about potentially malicious activities related to online transactions such as unauthorized transactions and altering and breaching transaction information [6, p. 34]. Privacy concern refers to consumers' risk perception of the likelihood that a retailer or other unauthorized entities inappropriately use their confidential information without their permission [7].

To mitigate these concerns, online vendors have developed several assurance mechanisms including assurance statements and third-party assurance seals. Designated to e-vendors by third-party industry authorities, assurance seals are indications of seal-bearing vendors' compliance with a high 
standard of technical and/or business practices. In contrast, assurance statements are vendor-initiated second-party efforts that convey business policies and procedures to warrant a safe shopping environment. Both third-party assurance seals and second-party vendors' assurance statements are important assurance mechanisms of e-commerce transactions for first-party online buyers to convince their purchasing decisions in e-commerce.

Although most previous studies have discussed the broad values of assurance mechanisms in increasing consumers trust $[9,10]$, it has been much silent on the joint effects of the two assurance mechanisms on online consumers' concerns, which are often simultaneously adopted by e-commerce vendors to alleviate concerns. Specifically, we contend that assurance mechanisms affect purchase intention through alleviating consumer concerns. This contrasts to prior studies which have implied an indirect effect, through trusting beliefs or risk perception, of web assurance features on consumer behaviors [11] but have not confirmed if such an effect is actually mediated by other constructs.

Motivated by the understudied area above, this study attempts to fill the gap by examining how these two assurance mechanisms affects consumers' concerns and their subsequent purchase intention. Specifically, we analyze the relationships among the pertinent factors to contend that the two assurance mechanisms positively affect consumers' purchase intention by alleviating the three focal online consumers' concerns- a mediation effect. In this study, we explicitly answer following two research questions: (1) "how do consumers' three focal online concerns (i.e., privacy concern, product and service, and transaction security concern) affect their purchase intention?" and (2) "how do third-party assurance seals and second-party security assurance statements influence online consumers' concerns and subsequently their purchase intention?"

This study makes several contributions. First, the results show that assurance statements outperform assurance seals in alleviating consumer concerns: (a) assurance statements reduce all three consumer concerns whereas assurance seals reduce transaction security concerns only; and (b) the effect of assurance statements on transaction security concern is greater than that of assurance seals. Second, we 
find that the effect of assurance statements and assurance seals on purchase intention is mediated by online consumers' concerns. As a consequence, the study sheds new insights on the effects of assurance mechanisms on the domain of information security and assurance. Finally, we report that assurance seals supplement the effects of assurance statements on privacy concern and product and service concern and that consumers' purchase decisions are affected by both information concern and privacy concern but not product/service concern which is a non-information security concern.

In the next section, we review literature on information security and assurance mechanisms and major inhibitors of online consumers' purchase decisions. Then we propose a research model and hypotheses. We present research methodology to validate the proposed research model. After presenting the data analysis and results, we discuss the findings of the study along with the theoretical contributions and practical implications.

\section{Literature review}

\subsection{Information security and assurance mechanisms}

To manage today's overwhelming issues of the interlocking fields of cyber security, information privacy, network security, and socio-technical aspects of security, information assurance mechanisms on security are needed. Information assurance contains all the elements of information security (i.e., confidentiality, integrity, and availability) and provides a view of information protection that includes assurance mechanisms in different levels of controls (e.g., technology, operations, and security education \& training awareness programs). According to Maconachy, Schou, Ragsdale and Welch [12, p. 306] INFOSEC is define as "protection of information systems against unauthorized access to or modification of information, whether in storage, processing or transit and against the denial of service to authorized users, including those measures necessary to detect, document, and counter such threats". The Information Systems Security Committee (NSTISSC) argues that infoirmation assurance incorporates protection, detection and reaction capabilities to protect and defend information and information systems [12]. Thus, information assurance is not only a measure for protecting information and information 
systems (the goal of information security) but also a control that helps users and IT professionals to detect and react against possible threats.

To respond to consumers' concerns about security and privacy in e-commerce, online vendors opt for information assurance mechanisms that help remedy concerns and negative feelings of their buyers. Two most popular assurance mechanisms recognized by the prior studies are third-party assurance seals and self-exposure assurance statements. Third-party assurances seals refer to "an assurance of an Internet vendor provided by a third-party certifying body such as a bank, accountant, consumer union, or computer company" [7, p. 550]. The web seals are created in order to decrease online consumers' concerns of online transactions [10]. The effect of seals on consumer purchasing behavior has been studied by a number of researchers. For example, McKnight et al. suggest assurance seals as important signaling tools for online shopping websites to increase their consumers' trust [9]. Yet their empirical results show that assurance seals do not impact on trust in the web business. Likewise, Kim, Ferrin and Rao [7] studied the effect of the assurance seals on consumers' perceived trust and risks regarding online shopping website. Their results show that assurance seals do not have any effect on consumers' trust while they have a significant effect on their perceived risk.

In addition to posting assurance seals, e-commerce websites publish their own assurance statements as a part of business privacy notice, security policy, or customer satisfaction guarantee (see Figure 1 for examples). Assurance statements assure and appease consumers that help will be provided and consumer concerns, issues, and problems will be resolved. Arcand et al. argue that assurance statements are another important mechanism to support online consumers [13]. Similarly, Bansal, Zahedi and Gefen [14] propose a set of assurance statements as an effective facilitator on consumers' provision of personal information during online transactions. These statements generally increase the consumers' perceived control of the website through their information. 


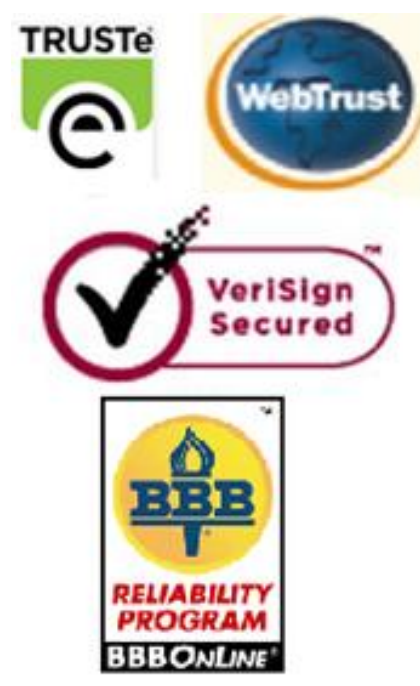

\section{Amazon.com Privacy Notice}

Last updated: March 3, 2014. To see what has changed, click here

Amazon com knows that you care how information about you is used and shared, and we appreciate your trust that we will do so carefully and sensibly. This notice describes our privacy policy. By visiting Amazon.com, you are accepting the practices described in this Privacy Notice.

- What Personal information About Customers Does Amazon com Gather?

- What About Cookies?

- Does Amazon com Share the information it Receives?

- How Secure is information About Me?

- What About Third-Party Advertisers and Links to Other Websites?

- Which Intormation Can I Access?

- What Choices Do I Have?

- Are Children Allowed to Use Amazon com?

- Does Amazon.com Participate in the Safe Harbor Program?

- Condations of Use, Notices, and Revisions

- Examples of Intormation Collected

\section{Figure 1. Examples of Assurance Mechanisms}

The findings from the existing literature are summarized in Table 1. While prior studies have shed insights on web assurance, they are limited in a number of ways which warrant new research. First, a vast majority of the existing research has focused on either self-initiated assurance statements [13, 15-17] or third-party assurance seals [7, 9, 11, 18-21] with few exceptions [22-24]. As a result, these studies miss the opportunities to compare the effects of both assurance features. Between the two features, one may play a dominant role or even displace the other when it comes to affecting online consumers. Second, findings on the effects of web assurance features are mixed to date. While some studies find constructive effects $[7,13,16,18-20,22,25]$, others report either a lack of consturctive effects $[7,9,11,13,22]$ or even destructive effects $[13,16]$. Although the mixed findings may be attributed to the choice of assurance constructs used and the research designs employed, they clearly suggest that more research needs to be conducted in order to gain an improved understanding of how web assurance features affect individual users. Third, in the study of web assurance, existing literature has predominately borrowed the theoretical lens of trust $[7,9,11,16,18,19,22,25]$. Findings on whether web assurance affects consumer trust does not explain if these features successfully alleviate consumer concerns over uncertainties in online purchase. Put differently, prior studies haven't tested if constructs such as trusting beliefs relay (i.e., mediate) the effect of web assurance mechanisms on user behavior. Finally, many studies examine 
web assurance features through their presence (yes/no) [7, 9, 13, 15, 18, 20, 21, 25], users' reading/notice of assurance features (yes/no) [11, 16], and users' awareness/attention to assurance features (high/low) $[11,24]$. As a consequence, they have failed to capture online consumers' subjective evaluation of these mechanisms, which is important for understanding how consumers interpret and evaluate these safeguards. Considering these existing gaps, in this study, we develop a conceptual model to theorize the values, as perceived by online consumers, of the two web assurance features in addressing consumer concerns, which may in turn promote consumer purchase intention. As discussed before, little is known if any one of the two web assurance features proves to be more effective in reducing the key concerns held by online consumers. Nor does the literature suggest if the positive effect of one assurance feature will be displaced by the other feature. As most e-commerce websites utilize both assurance features, our model helps develop a holistic view on how co-existence of the two features jointly affects average users. When they are co-present, their relative effects in promoting purchase intention may be contingent upon how individual consumers value internal assurance versus external assurance. We further project that the effects of both web assurance mechanisms on user purchase intention may be mediated by the key concerns, a mediating effect that has not been explored in the past.

Table 1. Summary of Key Findings from Literature on Assurance Mechanisms

\begin{tabular}{|l|l|l|}
\hline \multicolumn{1}{|c|}{ Studies } & $\begin{array}{l}\text { Constructs related to } \\
\text { Assurance } \\
\text { Mechanism }\end{array}$ & \multicolumn{1}{c|}{ Key Findings } \\
\hline $\begin{array}{l}\text { Arcand, et al. } \\
{[13]}\end{array}$ & $\begin{array}{l}\text { Presence of privacy } \\
\text { statement (yes/no), } \\
\text { reading privacy } \\
\text { statement (yes/no) }\end{array}$ & $\begin{array}{l}\text { First, the mere presence of privacy statement has a positive } \\
\text { impact on perceived control over privacy. Second, the mere } \\
\text { presence of privacy statement has no effect on perceived trust. } \\
\text { Third, reading the privacy statement reduces perceived control } \\
\text { and perceived trust in study 1 while it casts no effect in study } 2 .\end{array}$ \\
\hline $\begin{array}{l}\text { Belanger et al. } \\
\text { [23] }\end{array}$ & $\begin{array}{l}\text { User ranking of the } \\
\text { importance of } \\
\text { assurance statements } \\
\text { and seals }\end{array}$ & $\begin{array}{l}\text { First, customers rank privacy statements and seals (security and } \\
\text { privacy) as less important than security features. Second, } \\
\text { customers rank privacy statements, security seals and privacy } \\
\text { seals of equal importance. }\end{array}$ \\
\hline $\begin{array}{l}\text { Bansal et al. } \\
{[22]}\end{array}$ & $\begin{array}{l}\text { Privacy policy } \\
\text { adequacy, perceived } \\
\text { presence of third } \\
\text { party assurance }\end{array}$ & $\begin{array}{l}\text { First, third party assurance seals have no effect on trust in } \\
\text { website. Second, privacy policy adequacy has no effect on trust } \\
\text { in health website for customers with high privacy concern. } \\
\text { Third, the effect of privacy policy adequacy on trust in website } \\
\text { is positively moderated by privacy concern in e-commerce } \\
\text { websites and is negatively moderated privacy concern in } \\
\text { financial and health websites. }\end{array}$ \\
\hline
\end{tabular}




\begin{tabular}{|c|c|c|}
\hline Gauzente [17] & $\begin{array}{l}\text { User ratings of } \\
\text { perceived } \\
\text { "reassuringness" of } \\
\text { assurance statements }\end{array}$ & $\begin{array}{l}\text { First, highly concerned consumers will demand more regarding } \\
\text { privacy and security statement, as suggested by correlation } \\
\text { analysis. Second, consumers rank security and control as the } \\
\text { most component of privacy and security statement. }\end{array}$ \\
\hline Hu et al. [18] & $\begin{array}{l}\text { Presence of assurance } \\
\text { seals (yes/no) }\end{array}$ & $\begin{array}{l}\text { First, there exists an attenuating interaction effects rather than } \\
\text { synergistic effects between privacy and the security functions } \\
\text { and the transaction-integrity functions of assurance seals and } \\
\text { between the privacy. Second, the effects of security or } \\
\text { transaction-integrity assurance function on consumers' initial } \\
\text { trust are moderated by the privacy assurance function. }\end{array}$ \\
\hline Hu et al. [25] & $\begin{array}{l}\text { Presence of assurance } \\
\text { seal (yes/no) }\end{array}$ & $\begin{array}{l}\text { First, a seal that promotes privacy, security, or transaction- } \\
\text { integrity increases consumers' trust toward an online store that } \\
\text { displays the seal. Second, a seal that promotes two or more } \\
\text { assurance doesn't increase consumers' trust than a seal that } \\
\text { promotes only one assurance. }\end{array}$ \\
\hline Kim [19] & $\begin{array}{l}\text { Perceived importance } \\
\text { of third-party seals }\end{array}$ & $\begin{array}{l}\text { Perceived importance of third-party seals is positively related to } \\
\text { consumer trust in e-vendors in a Type II (i.e., collectivist-strong } \\
\text { uncertainty avoidance-high long-term orientation-high context) } \\
\text { culture but not in a Type I (i.e., individualistic-weak } \\
\text { uncertainty avoidance-low long-term orientation-low context) } \\
\text { culture. }\end{array}$ \\
\hline Kim et al. [7] & $\begin{array}{l}\text { Presence of third- } \\
\text { party seals (yes/no) }\end{array}$ & $\begin{array}{l}\text { First, the presence of third-party seal reduces perceived overall } \\
\text { risk. Second, presence of third-party seals doesn't reduce } \\
\text { perceived trust. }\end{array}$ \\
\hline Kim et al. [15] & $\begin{array}{l}\text { Presence of assurance } \\
\text { statements (yes/no) }\end{array}$ & $\begin{array}{l}\text { First, companies that deal with monetary transactions describe } \\
\text { business integrity in their assurance statements more than other } \\
\text { companies. Second, more reputable companies describe more in } \\
\text { their assurance statements than less reputable companies. }\end{array}$ \\
\hline Kim et al. [24] & $\begin{array}{l}\text { Awareness of web } \\
\text { assurance features, } \\
\text { perceived importance } \\
\text { of web assurance } \\
\text { features }\end{array}$ & $\begin{array}{l}\text { First, consumers' awareness of web assurance mechanisms } \\
\text { positively affects their perceived importance of web assurance } \\
\text { mechanisms. Second, consumers' awareness of web assurance } \\
\text { mechanisms is affected by their security concern. Second, } \\
\text { consumers' awareness of web assurance mechanisms is not } \\
\text { affected by their privacy concern. }\end{array}$ \\
\hline $\begin{array}{l}\text { Kimery and } \\
\text { McCord [11] }\end{array}$ & $\begin{array}{l}\text { Assurance seal } \\
\text { notice, and attention } \\
\text { to seal }\end{array}$ & $\begin{array}{l}\text { First, consumers' seeing an assurance seal has not effect on their } \\
\text { trust in an e-retailer. Second, increased attention to an assurance } \\
\text { seal has no effect on consumer trust. }\end{array}$ \\
\hline $\begin{array}{l}\text { McKnight et } \\
\text { al. [9] }\end{array}$ & $\begin{array}{l}\text { Presence of assurance } \\
\text { seals (yes/no) }\end{array}$ & $\begin{array}{l}\text { First, privacy seals do not affect trust in web services. Second, } \\
\text { industry seals does not affect trust in web services. }\end{array}$ \\
\hline $\begin{array}{l}\text { Nemati and } \\
\text { Dyke [16] }\end{array}$ & $\begin{array}{l}\text { Presence of privacy } \\
\text { statements (yes/no) }\end{array}$ & $\begin{array}{l}\text { First, the presence of privacy statement increases consumer } \\
\text { trust. Second, the presence of statement increases perceived } \\
\text { risks as well. The authors attribute this negative effect to the } \\
\text { increased awareness of potential threats that such statements } \\
\text { bring to customers. Finally, changes in privacy statement } \\
\text { contents don't affect perceived trust and risk. }\end{array}$ \\
\hline Park et al. [21] & $\begin{array}{l}\text { Presence of assurance } \\
\text { seals (yes/no) }\end{array}$ & $\begin{array}{l}\text { First, the presence or absence of third-party assurance seals } \\
\text { moderates the effect of service performance on customer } \\
\text { satisfaction. Second, the presence or absence of third-party } \\
\text { assurance seals moderates the effect of service performance on } \\
\text { repeat purchase intention. Third, customer satisfaction for }\end{array}$ \\
\hline
\end{tabular}




\begin{tabular}{|l|l|l|}
\hline & & $\begin{array}{l}\text { vendors with seals has less diminishing sensitivity than for } \\
\text { vendors without seals. }\end{array}$ \\
\hline Zhang [20] & $\begin{array}{l}\text { Displaying assurance } \\
\text { seals (yes/no) }\end{array}$ & $\begin{array}{l}\text { First, displaying information and reliability assurance seals } \\
\text { increases consumers' willingness to buy (WTB). Second, } \\
\text { displaying reliability assurance seals increases WTB than } \\
\text { information assurance seals. Third, information assurance seals } \\
\text { increase WTB for online commodity products whereas } \\
\text { reliability assurance seals increase WTB for both online } \\
\text { commodity and look-and-feel products. Fourth, trust promoting } \\
\end{array}$ \\
& $\begin{array}{l}\text { seals affect WTB of inexperienced online shoppers more than } \\
\text { they affect experienced shoppers. }\end{array}$ \\
\hline
\end{tabular}

\subsection{Major inhibitors of online consumers' purchase decisions}

While product purchase decisions in the offline context are mainly affected by the price and quality of product [26], online purchase decisions are possibly affected by other additional factors. To date, several studies have explored the main drivers of online purchase decisions. Brown et al. suggest that product type, prior purchasing experience from the website, and gender may effect online consumers' purchase decisions [27]. In addition, Bai, Law and Wen [28] and Qureshi, Fang, Ramsey, McCole, Ibbotson and Compeau [29] note that website quality affect consumers' purchase intention through its effect on consumer satisfaction. Likewise, Poddar, Donthu and Wei [30] argue that consumer personality as well as website quality are pertinent to consumers' online purchase intention. Park, Lennon and Stoel [31] further point out that the visual presentation of goods in websites may relate to consumers' purchase intentions. Still, Chen, Hsu and Lin [3] show that a number of attributes such as usability, delivery, and convenience are associate with purchase intention. Otim and Grover [32] address that pre-purchase, post-purchase, and transaction related services along with product satisfaction and pricing strategy affect online consumers' purchase decisions.

The existing literature has explored the potential inhibitors of consumers' online purchase decisions. Due to the information asymmetry, consumers make decisions with limited information [7] while vendors may behave opportunistically to exploit consumers' trust [33]. Therefore, consumers' purchase decisions are inherent to uncertainties [34, 35]. Through an extensive review of prevailing literature on online shopping adoption, Chang, Cheung and Lai [36] highlight several factors that affect 
online consumers' purchase decisions. These factors address information privacy, transaction security, and vendor fraudulent behavior such as product scams and credit card faults. By surveying online consumers, Miyazaki and Fernandez [6] classify online shopping concerns into four categories: privacy, system security, security, and inconvenience. In their research, privacy concern is associated with the infringement by retailers to disclose consumers' information to others; system security refers to unauthorized third-party access to consumers' information; security describes potential non-delivery of ordered goods; inconvenience addresses several issues related to online shopping such as the inability for one to touch or feel the actual goods. Synthesizing prior studies, this study mainly focuses on three focal consumers concerns (i.e., privacy, security, and product \& service concerns) to theorize their potential associations to consumers' purchase intention.

Among the concerns that matter to online consumers in their decision making, security and privacy stand out as two fundamental issues [37]. Online sellers collect different types of consumer information such as name, address, phone number, email address, etc. Once captured, consumer information could be transferred to third-parties, reused without consent, or exploited for secondary use [38]. Therefore, for online consumers, privacy is an important concern [7]. Privacy concern is on the rise in the recent years as a result of the use of pervasive technologies [39]. It has been investigated in an extensive body of the literature as an important factor that affects individuals' decision making [40]. Smith, Dinev and Xu [41] report privacy experience, privacy awareness, personality awareness, demographic differences, and culture as important antecedents of privacy concern.

In parallel, Furnell and Karweni [42] and Salisbury, Pearson, Pearson and Miller [43] stress that security concern is one of the most enduring theme of e-commerce. This view is also held by Ranganathan and Ganapathy who recognize security as the single most important predictor of online purchase intention [44]. As a Wild West, the Internet serves as an open platform that is accessed by cyber criminals on a 24-7 basis. The lack of effective regulation, the lack of security awareness, and the underpreparedness of online vendors all render e-commerce activities susceptible to attacks. A wide array of 
cyber-attacks such as hacking, social engineering, and dissemination of malwares pose a constant threat to vendors and the consumer data that they retain [45]. Casaló, Flavián and Guinalíu [46] suggest that it is important to study both concerns yet the prevailing literature has primarily on one over the other. Recent studies sometimes doubt the significance of these concerns on consumers' decision making. Van Slyke et al., for example, find that privacy does not have a direct negative effect on online transaction [47].

\section{Research model and hypotheses}

A number of studies in the literature discuss the relationship between risk and purchase intention in online shopping [e.g., 7, 36, 48]. The valance framework by Peter and Tarpey Sr [49] addresses that consumers evaluate products based on desirable and undesirable features. They argue that in the risk-benefit typology there are three strategies that consumers can decide to purchase a product: (1) minimizing perceived risk, (2) maximizing perceived return or benefit, and (3) maximizing net benefit, which is defined as the difference between perceived benefit and risk. Based on the valance framework, consumers' concerns are important factors that affect consumers' purchase decision when buying a product from a specific vendor. Consumer concerns may be cultivated by a broad range of factors with examples such as consumers' perceived risks.

In online transactions, consumers must surrender their private information in return of goods or services. Accordingly, information security and privacy issues render chief issues that concern online buyers. Procedural fairness theory argue that individuals are willing to disclose their information if they perceive that their information is used fairly and if they consider that they will not suffer negative consequences [50, 51]. Procedural fairness refers to "the perception by the individual that a particular activity in which they are a participant is conducted fairly" [52, p. 107]. Fair information practice is based on two concepts: (1) people have the right to know why their information is collected and (2) people should have the right to control the way their information is used [52]. Procedural fairness theory suggests that transparency of vendor's actions is an important mechanism to mitigate consumers' concerns regarding their information $[51,53]$. To this end, e-commerce vendors often employ two important 
assurance mechanisms as suggested by the web assurance literature [54]: (1) third-party assurance seals [55] and (2) assurance statements [56, 57]. Assurance statements describe e-vendors' rules regarding issues such as consumers' information collection and usage [54]. Meanwhile, assurance seals increase consumers' perceive control over the vendors' processes. Assurance granting bodies control and certify all the processes that the e-vendors adopts in managing the information security and privacy [7]. According to the two concepts of the fair information practice in procedural fairness theory mentioned before, assurance statements increase the transparency of the security and privacy features used by the vendors and assurance seals ensure consumers about the control over the vendors' actions. Therefore, we suggest that assurance statements and assurance seals influence consumer concerns negatively. In addition, the uncertainties with vendor opportunism render a valid concern when a consumer worries about the potential of mis-presentation of product information, non-delivery, or failure to honor after-sale warranty. That is, a consumer may become worry about the potential of presentation of incorrect product information, non-delivery, or failure to honor after-sale warranty - which is termed as product and service concerns in this research. The three individual concerns resemble the major categories of online consumers' concerns as proposed by Miyazaki and Fernandez [6]. In line with the findings of Miyazaki and Fernandez [6] as well as e-commerce related risk-return typology, we propose a research model (Figure 2). 


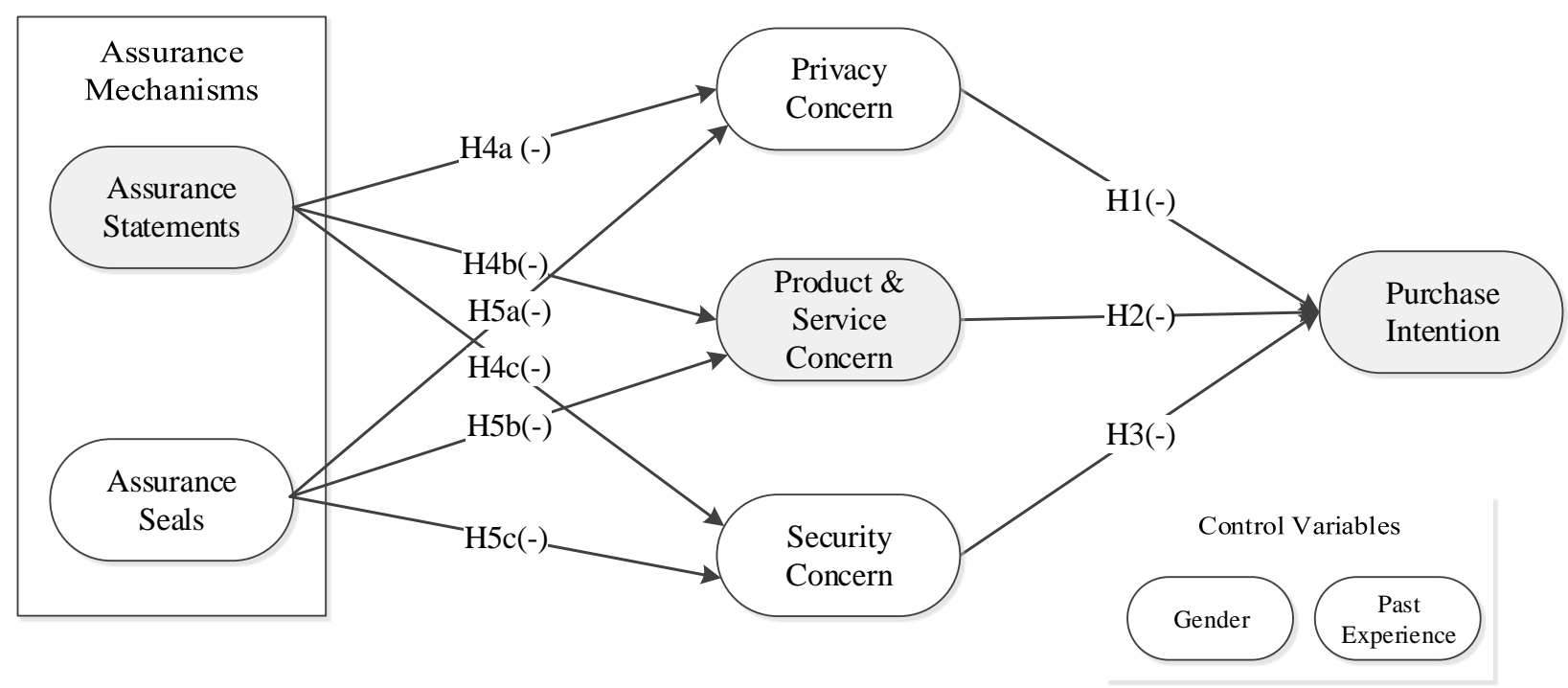

Figure 2. Research Model

The research model addresses three different concerns of online consumers and suggests their effects on consumers' purchase intention; two assurance mechanisms (i.e., assurance statements and assurance seals) lessen the effects of three different concerns. Further, we propose the effects of assurance mechanisms indirectly influence on purchase through three different concerns as mediators in the model. The mediating effects of three different concerns for each assurance mechanism are hypothesized separately as H6a and H6b in the hypothesis development section later.

Westin [58, p. 7] defines information privacy as "the claim of individuals, groups, or institutions to determine for themselves when, how, and to what extent information about them is communicated to others". Belanger, Hiller and Smith [37] argue that privacy concern as one key factor influences online consumers' purchase intention. Privacy concern refers to consumers' worry about the likelihood that a retailer tries to use their confidential information without their permission [7]. Illegal use of consumers' personal information has harmful consequences, such as identity theft [59]; therefore, privacy concerns is one of major worries of online consumers [e.g., 6, 60]. Privacy concern may cause online consumers to expect negative outcomes from online shopping. In fact, online retailers acquire a great deal of information from consumers compared to other types of commerce, which can increase consumer concern and negatively affect their purchase intention. Thus, if online consumers perceive that online retailers inappropriately manage their personal information, they may not trust the online retailers, in turn, forming 
a hindrance, which will decrease their willingness to make further business relationships with the online retailers. Therefore, we hypothesize that:

\section{H1: Online consumers' privacy concern negatively affects their purchase intention.}

Product and service concern refers to uncertainty about fraudulent behavior of an online retailer in association with products and services. Consumers' concern about a product or service could be related to different aspects of the services. Examples are such as on time delivery or flexible return policies of a product. E-commerce literature underscored product and service concern as one of the important issues for online consumers [6]. Online consumers who have more concerns about possible issues with the product or service that they plan to procure from an online may feel more uncertainties with regard to buying a product or service. Therefore, they may have less intention to shop online. In fact, many prefer to shop from other channels such as offline shopping in order to avoid such risks. So we hypothesize that:

\section{H2: Online consumers' product and service concern negatively affects their purchase intention.}

Transaction security concern refers to "concerns about potentially malicious individuals who breach technological data protection devices to acquire consumers' personal, financial, or transactionoriented information" [6, p. 34]. Also termed as "system security", transaction security concern indicates the importance of online consumers' worries about their transactional information. One of the distinguished features of e-commerce is making a transaction online, which provides convenience and flexibility of shopping. If online consumers have concerns about their online transaction information that

they share with the online retailer or they believe that online retailer cannot safeguard secure transactions from unauthorized access such as hacking, they may avoid purchasing from the Internet. Based on the above arguments, we hypothesize that:

H3: Online consumers' transaction security concern negatively affects their purchase intention.

Assurance statements refer to vendors' words or pledges described in their websites to ensure their consumers about appropriate controls over the sensitive transaction information of their customers 
[61]. These assurance statements explain the purpose and intended use of consumer information and convey their privacy handling policy to their consumers. It, therefore, helps increase consumers' perceived control over their information which has been shared with these websites [13]. By increasing the perceived control over personal information, consumers develop less uncertainties about the information that their share with the e-commerce website. Xu, Teo and Tan [62], for example, suggest that privacy assurance statement is an effective mechanism that reduces users' perceived privacy risk in the context of location-based services. Likewise, Belanger et al. comment that the presence of strong assurance statements is the first step to insure consumers that their personal information are inaccessible by unauthorized parties [37]. In addition, the presence of assurance statements is indicative of vendors' benevolence in sustaining consumers' welfare - protection of private information. It, therefore, fosters consumers' trusting belief in online stores. Following the trust transfer mechanism [63-65], consumers tend to develop a high level of trusting belief towards an online store with respect to other qualities such as product and services. As consumers make an inference about vendors' care of their privacy, they subsequently expect that the online store will behave in a similar manner in addressing other important matters. For example, such a trustful website would be likely to commit to its claims about the product and service provided so the consumer may have less concern. Finally, we contend that assurance statements may alleviate consumer's concern on transaction security. Transaction security relates to unauthorized access to consumer information, which is often addressed in assurance statements which prevent all types of data misuse including unauthorized access. As a result, the use of assurance statements by an online store provides a partial remedy to threats on transaction security. Accordingly, consumers may become less concerned regarding the disclosure of their transaction data such as their credit card information, etc. We hypothesize that:

H4a: Assurance statements diminish online consumers' privacy concern.

H4b: Assurance statements diminish online consumers' product and service concern. H4c: Assurance statements diminish online consumers' transaction security concern. 
In contrast to assurance statements which are developed by individual e-commerce vendors as the second-party of e-commerce transactions, assurance seals are created by third-party professional assurance services. Market leading assurance seals are such as Web Assured, BBB Online, WebTrust, and TRUSTe. These seals are developed following a common framework (e.g., a set of core principles and criteria) to address common issues in business management and technology usage. Assurance seals are provided by a third party to insure consumers that proper measures and practices have been adopted by the vendors, with important tasks such as the provision of goods and services, safeguarding credit card transactions, and management of consumer data [66]. E-commerce websites use third-party assurance seals to ensure their consumers that their business and website meet the industry standards and guarantee the required standard quality of their services at least. Assurance seals are obtained when an online business develops adequate policies and procedures that achieve the objectives of core principles established by the seal-granting authorities. The key principles often concern a wide range of imperative issues such as information confidentiality, service availability, processing integrity, protection against unauthorized access (both physical and logical), and privacy [66]. The achievement of assurance seal certification serves the proof that an e-commerce transaction is attuned to the potential risks and are equipped with controls that address those risks. In addition, e-commerce firms are monitored by the sealgranting authorities to ensure continuous compliance. Mechanisms that a website applied to increase the control of data transmission to or from that website negatively affect consumers concerns about their privacy [67]. The existence of the assurance seals also indicates that the website contains security features to conform to the industry standards [68]. As assurance seals signifies trust, consumers expect assurance seals certified websites to display integrity [69]. Subsequently, consumers develop the beliefs that vendors will keep their promises in other practices such as the provision of quality product and services. Therefore, we posit that:

H5a: Assurance seals diminish online consumers' privacy concern.

H5b: Assurance seals diminish online consumers' product and service concern. H5c: Assurance seals diminish online consumers' transaction security concern. 
Presence of assurance statements on an online shopping website affects consumers' trust in the vendor as well as consumers' perceived control [13]. This is because assurance statements signify vendors' respect of consumer privacy and indicates vendors' intention to properly manage consumers' information. Therefore, assurance statements help mitigate uncertainties that are associated with the future use of consumer information and subsequently they ease consumer fear. Bansal, Zahedi and Gefen [14] suggest that assurance statements promote users to interact with an organization by supplying personal information to facilitate transactions. Because assurance statements affect consumer's purchase intention by alleviating their concerns about the uncertainties, we expect the effect of assurance statements on purchase intention is mediated by consumer concerns. The assurance seals have similar role as assurance statements. Kimery and McCord [8] argued that e-commerce websites, which have specific assurance seals, agreed to apply the third party's standards and use specific technology. The assurance seal is a mechanism which is used by e-commerce websites to increase perceive control in the consumers [13]. It is applied by online shopping websites to reduce consumers' perceived concerns of online transactions [10]. Assurance seals convince buyers that a website has been controlled and monitored by the third party and that it has met the acceptable level of service. Given that third-party assurance seals affect consumer's purchase intention through reducing their concerns about the risks exists in online shopping, we expect its effect on purchase intention is mediated by the key concerns. Thus, we hypothesize that:

H6a: Online consumers' concerns mediates the effect of assurance statements on purchase intention. H6b: Online consumers' concerns mediates the effect of assurance seals on purchase intention.

We also include gender and past experience with the e-commerce website as control variables, because online consumers may have different perceptions on assurance mechanisms and different level of concerns in terms of gender and e-commerce experience [e.g., 70, 71] 


\section{Methodology}

\subsection{Instrument development and data collection}

To measure all research constructs, measurement items from previously validated were identified and adjusted. All measurement items are listed in Appendix A. A set of survey data was collected from students in a large public university in the southwest United States. Survey responses were only from students who had an ongoing shopping experience. We asked them about their ongoing attempts to buy a product online and to answer the questions on the survey based on their shopping experience. The original sample consists of 335 responses. After removing incomplete and invalid responses, we ended up with 321 usable responses. Table 2 summarizes the demographics of the participants in the study.

Table 2. Demographics

\begin{tabular}{|l|l|l|}
\hline Gender & Age & Academic status \\
\hline 215 Male $(67 \%)$ & 18-21 years old: $135(42 \%)$ & Undergraduate: $293(91 \%)$ \\
106 Female $(33 \%)$ & $\begin{array}{l}\text { 22-25 years: } 96(33 \%) \\
\text { 26 years or older: } 90(25 \%)\end{array}$ & Graduate students: $28(9 \%)$ \\
\hline
\end{tabular}

\subsection{Measurement and structural model}

We used Partial Least Square (PLS) with Smart PLS as our statistical analysis tool to test the proposed hypotheses. PLS uses metric properties of the scales in order to measure variables, as well as the strength and direction of relationships among these variables [72]. PLS offers a wide range of benefits which are valued in this research: (1) suitability to exploratory research where relationships have not been previously tested, (2) tolerance of possible violations of multivariate normality and use of non-interval scaled data, (3) avoidance of parameters estimation biases, and (4) independence of parameter estimation from sample size [73]. Our study explores the joint effects of two popular e-commerce design features assurance statements and third-party assurance seals - on consumers' purchase intention, which has received little attention in the existing literature. PLS is therefore appropriate. We conducted a three step analysis procedure: (1) analyzing the measurement model in order to assess item reliability and validity, (2) checking the common method bias, and (3) analyzing structural model assessment to assess the model's predictive power. 
The adequacy of the measurement model is an important concern which is assessed by analyzing reliability, internal consistency, and discriminant validity [74]. Internal consistency of each construct is assessed by analyzing Cronbach's alpha, composite reliability, and Average Variance Extracted (AVE) [75]. Cronbach's alpha and composite reliability are supposed to be at least 0.50 [76] while AVE is more than 0.50 [77]. In Table 3, the diagonal values represent the square root of AVE which is measured for variance shared between a construct and its indicators, or convergent validity. According to Table 3, Cronbach's alpha, composite reliability, and AVE values prove the internal consistency of constructs based on the above constraints.

Table 3. Reliability and Validity

\begin{tabular}{|l|c|c|c|c|c|c|c|c|c|}
\hline Construct & $\mathbf{A V E}^{\mathrm{a}}$ & $\mathbf{C R}^{\mathbf{b}}$ & $\mathbf{C A}^{\mathbf{c}}$ & $\mathbf{1 .}$ & $\mathbf{2 .}$ & $\mathbf{3 .}$ & $\mathbf{4 .}$ & $\mathbf{5 .}$ & $\mathbf{6 .}$ \\
\hline $\begin{array}{l}\text { 1. Assurance } \\
\text { Statements }\end{array}$ & 0.84 & 0.94 & 0.90 & $\mathbf{0 . 9 2}$ & & & & & \\
\hline 2. Assurance Seals & 0.82 & 0.93 & 0.89 & 0.51 & $\mathbf{0 . 9 1}$ & & & & \\
\hline 3. Privacy Concerns & 0.68 & 0.91 & 0.88 & -0.45 & -0.25 & $\mathbf{0 . 8 2}$ & & & \\
\hline $\begin{array}{l}\text { 4. Product \& Service } \\
\text { Concern }\end{array}$ & 0.72 & 0.89 & 0.83 & -0.26 & -0.12 & 0.34 & $\mathbf{0 . 8 5}$ & & \\
\hline $\begin{array}{l}\text { 5. Transaction } \\
\text { Security Concern }\end{array}$ & 0.78 & 0.95 & 0.93 & -0.65 & -0.52 & 0.30 & 0.31 & $\mathbf{0 . 8 8}$ & \\
\hline \begin{tabular}{l} 
6. Purchase Intention \\
\hline
\end{tabular} & 0.85 & 0.95 & 0.91 & 0.46 & 0.37 & -0.31 & -0.21 & -0.57 & $\mathbf{0 . 9 2}$ \\
\hline Note. ${ }^{\text {a Average Variance Extracted, }}{ }^{\mathrm{b}}$ Composite Reliability, ${ }^{\mathrm{c}}$ Cronbach's Alpha. \\
\hline
\end{tabular}

There are two constraints for examination of discriminant validity. First, AVE values are supposed to be greater than off-diagonal correlations. Second, each construct related item must load highly on the construct it is measuring and cross-loadings are supposed to be lower than the withinconstruct item loadings [78]. Table 4 reflects the loading values of all the items used in the measurement instrument. The two criteria for examination of discriminant validity are acceptable.

Common method bias could be important source of measurement errors [79]. According to Campbell and Fiske [80] presence of common method bias in measurement causes erroneous conclusions. We apply two different methods to evaluate check the presence of common method bias. We use Harman's single factor test as the first method. According to Podsakoff, MacKenzie, Lee and Podsakoff [79], there are two conditions for the presence of common method bias: (1) presence of a single factor in 
the factor analysis, (2) presence of a single factor which accounts for the majority of the covariance among the variables. We conduct unrotated factor analysis for all 22 items and the results indicate 6 factors account for 79 percent of the variance in the data while the first factor accounts for less than 50\% of the total variance. Therefore, using Harman's single factor test we conclude that common method bias is unlikely to be present in our measurement model.

Table 4. Factor Loadings

\begin{tabular}{|c|c|c|c|c|c|c|c|c|}
\hline Item & Mean & $\begin{array}{c}\text { Std. } \\
\text { Deviation }\end{array}$ & $\begin{array}{c}\text { Assurance } \\
\text { Statements }\end{array}$ & $\begin{array}{c}\text { Assurance } \\
\text { Seals }\end{array}$ & $\begin{array}{c}\text { Privacy } \\
\text { Concerns }\end{array}$ & $\begin{array}{c}\text { Product \& } \\
\text { Service } \\
\text { Concern }\end{array}$ & $\begin{array}{c}\text { Security } \\
\text { Concern }\end{array}$ & $\begin{array}{c}\text { Purchase } \\
\text { Intention }\end{array}$ \\
\hline PAS1 & 5.45 & 1.33 & $\mathbf{0 . 9 2}$ & 0.45 & -0.37 & -0.28 & -0.41 & 0.43 \\
\hline PAS2 & 5.55 & 1.20 & $\mathbf{0 . 9 4}$ & 0.45 & -0.46 & -0.23 & -0.32 & 0.46 \\
\hline PAS3 & 5.68 & 1.56 & $\mathbf{0 . 8 9}$ & 0.41 & -0.41 & -0.21 & -0.47 & 0.37 \\
\hline AS1 & 5.13 & 1.55 & 0.27 & $\mathbf{0 . 9 3}$ & -0.23 & -0.12 & -0.51 & 0.34 \\
\hline AS2 & 5.10 & 1.47 & 0.37 & $\mathbf{0 . 9 3}$ & -0.23 & -0.08 & -0.46 & 0.33 \\
\hline AS3 & 5.02 & 1.53 & 0.35 & $\mathbf{0 . 8 5}$ & -0.24 & -0.14 & -0.45 & 0.34 \\
\hline PC1 & 3.52 & 1.53 & -0.29 & -0.12 & $\mathbf{0 . 7 0}$ & 0.36 & 0.17 & -0.16 \\
\hline PC2 & 3.00 & 1.58 & -0.36 & -0.19 & $\mathbf{0 . 8 8}$ & 0.21 & 0.19 & -0.29 \\
\hline PC3 & 3.09 & 1.62 & -0.41 & -0.23 & $\mathbf{0 . 9 1}$ & 0.26 & 0.24 & -0.29 \\
\hline PC4 & 3.59 & 1.76 & -0.32 & -0.16 & $\mathbf{0 . 7 3}$ & 0.33 & 0.23 & -0.20 \\
\hline PC5 & 2.92 & 1.58 & -0.46 & -0.29 & $\mathbf{0 . 8 8}$ & 0.30 & 0.35 & -0.31 \\
\hline P\&SC1 & 3.63 & 1.74 & -0.13 & -0.03 & 0.22 & $\mathbf{0 . 7 9}$ & 0.16 & -0.13 \\
\hline P\&SC2 & 3.65 & 1.78 & -0.15 & -0.06 & 0.26 & $\mathbf{0 . 8 4}$ & 0.20 & -0.10 \\
\hline P\&SC3 & 2.95 & 1.59 & -0.30 & -0.17 & 0.35 & $\mathbf{0 . 9 1}$ & 0.36 & -0.24 \\
\hline TSC1 & 2.26 & 1.26 & -0.57 & -0.51 & 0.24 & 0.22 & $\mathbf{0 . 8 7}$ & -0.55 \\
\hline TSC2 & 2.35 & 1.39 & -0.54 & -0.42 & 0.21 & 0.25 & $\mathbf{0 . 8 5}$ & -0.47 \\
\hline TSC3 & 2.40 & 1.39 & -0.52 & -0.48 & 0.32 & 0.33 & $\mathbf{0 . 9 2}$ & -0.51 \\
\hline TSC4 & 2.28 & 1.31 & -0.42 & -0.47 & 0.30 & 0.31 & $\mathbf{0 . 9 2}$ & -0.50 \\
\hline TSC5 & 2.18 & 1.34 & -0.56 & -0.42 & 0.22 & 0.28 & $\mathbf{0 . 8 5}$ & -0.47 \\
\hline PI1 & 5.79 & 1.38 & 0.44 & 0.37 & -0.29 & -0.21 & -0.57 & $\mathbf{0 . 9 3}$ \\
\hline PI2 & 5.62 & 1.39 & 0.44 & 0.36 & -0.31 & -0.21 & -0.53 & $\mathbf{0 . 9 5}$ \\
\hline PI3 & 5.57 & 1.56 & 0.40 & 0.29 & -0.26 & -0.13 & -0.47 & $\mathbf{0 . 8 9}$ \\
\hline & & & & & & & & \\
\hline
\end{tabular}

As the second method to test presence of the common method bias we used the approach suggested by Podsakoff, MacKenzie, Lee and Podsakoff [79] following the procedure of Liang, Saraf, Hu and Xue [81]. The results of the test (See Table 5) indicate that the theoretical constructs are loaded highly significant compared to common method bias construct. In fact, in almost all cases the items are 
loaded in significantly on common method bias construct. Thus we conclude that the common method bias does not seem to be serious issue in our measurement model.

Table 5. Common Method Bias Analysis

\begin{tabular}{|c|c|c|c|c|c|}
\hline Construct & Item & $\begin{array}{l}\text { Substantive Factor } \\
\text { Loading (R1) }\end{array}$ & $\mathbf{R} 1^{2}$ & $\begin{array}{c}\text { Method Factor } \\
\text { Loading (R2) }\end{array}$ & $\mathbf{R} 2^{2}$ \\
\hline \multirow{3}{*}{$\begin{array}{l}\text { Assurance } \\
\text { Statements }\end{array}$} & PAS1 & $0.929 * * *$ & 0.863 & 0.014 & 0.000 \\
\hline & PAS2 & $0.925 * * *$ & 0.856 & -0.013 & 0.000 \\
\hline & PAS3 & $0.895 * * *$ & 0.801 & -0.001 & 0.000 \\
\hline \multirow{3}{*}{ Assurance Seals } & AS1 & $0.933 * * *$ & 0.870 & -0.004 & 0.000 \\
\hline & AS2 & $0.964 * * *$ & 0.929 & 0.042 & 0.002 \\
\hline & AS3 & $0.815^{* * *} *$ & 0.664 & -0.043 & 0.002 \\
\hline \multirow{5}{*}{ Privacy Concern } & PC1 & $0.761 * * *$ & 0.579 & -0.059 & 0.003 \\
\hline & $\mathrm{PC} 2$ & $0.917 * * *$ & 0.841 & -0.069 & 0.005 \\
\hline & $\mathrm{PC} 3$ & $0.911 * * *$ & 0.830 & -0.012 & 0.000 \\
\hline & PC4 & $0.743 * * *$ & 0.552 & -0.002 & 0.000 \\
\hline & PC5 & $0.777 * * *$ & 0.604 & $0.135^{*}$ & 0.018 \\
\hline \multirow{3}{*}{$\begin{array}{c}\text { Product and Service } \\
\text { Concern }\end{array}$} & P\&SC1 & $0.900 * * *$ & 0.810 & $-0.091 *$ & 0.008 \\
\hline & P\&SC2 & $0.931 * * *$ & 0.867 & $-0.071 *$ & 0.005 \\
\hline & P\&SC3 & $0.751 * * *$ & 0.564 & $0.174 * *$ & 0.030 \\
\hline \multirow{5}{*}{ Security Concern } & TSC1 & $0.806 * * *$ & 0.650 & 0.067 & 0.004 \\
\hline & TSC2 & $0.916 * * *$ & 0.839 & -0.079 & 0.006 \\
\hline & TSC3 & $0.866^{* * *} *$ & 0.750 & 0.064 & 0.004 \\
\hline & TSC4 & $0.932 * * *$ & 0.869 & -0.006 & 0.000 \\
\hline & TSC5 & $0.898 * * *$ & 0.806 & -0.052 & 0.003 \\
\hline \multirow{3}{*}{ Purchase Intention } & PI1 & $0.879 * * *$ & 0.773 & 0.061 & 0.004 \\
\hline & PI2 & $0.941 * * *$ & 0.885 & -0.010 & 0.000 \\
\hline & $\mathrm{PI} 3$ & $0.952 * * *$ & 0.906 & 0.073 & 0.005 \\
\hline
\end{tabular}

In order to assess the structural model, we need to examine path coefficients and R-square values.

The path coefficients show the strengths of the relationships between independent and dependent variables in the model and R-square values indicate the predictive power of the model for dependent variables. To test the statistical significance of path coefficients, a bootstrapping technique was used. The overall results of the analysis are shown in Figure 3.

Both privacy concern and security concern have a negative and significant effect on purchase intention with $\beta=-.145$ and $\beta=-.473$, respectively, supporting $\mathrm{H} 1$ and $\mathrm{H} 3$. Unlike our expectation, 
product and service concern does not have significant influence on purchase intention, not supporting H2. Regarding the effects of two assurance mechanisms, assurance statements significantly reduce privacy concern $(\beta=-.436)$, product and service concern $(\beta=-.265)$ and security concern $(\beta=-.254)$; Assurance seals only significantly influences security concerns $(\beta=-.254)$. Thus, H4a, H4b, H4c, and H5c are supported while $\mathrm{H} 5 \mathrm{a}$ and $\mathrm{H} 5 \mathrm{~b}$ are not. Approximately $33 \%$ of variance in purchase intention is explained by the three focal concerns; About $21 \%, 24 \%$ and $48 \%$ of privacy concern, product and service concern, and security concern are explained by both assurance mechanism, respectively. Regarding control variables, the results show that gender and past experience with the e-commerce website are not significant as control variable in this study.

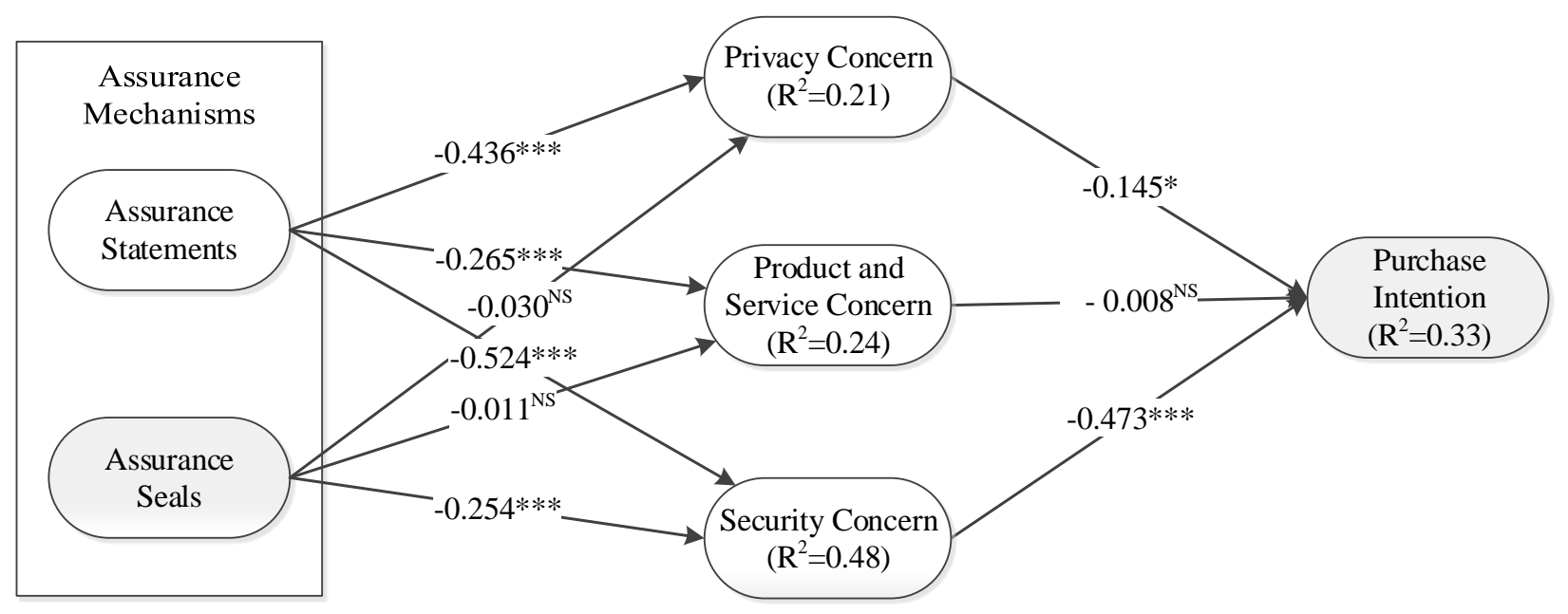

Figure 3. Results of PLS Analysis

Considering recent critiques of the traditional mediation tests [82] introduced by Baron and Kenny [83], this study applied the recent view on mediation analysis proposed by Preacher and Hayes $[84]]^{1}$. Our theoretical model corresponds to a multi-mediator model [86] in which the effect of independent variables (i.e., assurance seals and assurance statements) on the dependent variable (i.e., purchase intention) is mediated by online consumer concerns (H6a and H6b). We used the Preacher and Hayes [84] applying Preacher and Hayes [87] to test H6a and H6b. Table 6 summarizes the results of the

\footnotetext{
${ }^{1}$ This method overcomes some issues identified of traditional methods by focusing on ordinary least squares (OLS) regressions supplemented by analyses based on bootstrapping for assessment of indirect effects. According to [85], this method has been shown to constitute a more valid and powerful method for assessing indirect effects.
} 
mediation effect tests. According to Zhao, Lynch and Chen [82], if the bootstrap confidence intervals for the estimates of the indirect effects does not include zero and the indirect effect of independent variable on the dependent variable is significant then there is a mediation effect. Based on the results of the mediation tests, we can conclude that consumers' concerns mediate the effects of both assurance statements and assurance seals, supporting H6a and H6b.

Table 6. Preacher-Hayes Mediation Effect Test Results

\begin{tabular}{|c|c|c|c|c|c|c|}
\hline \multirow[t]{2}{*}{ Hypothesis } & \multirow[t]{2}{*}{ Relationship } & \multicolumn{2}{|c|}{$\begin{array}{c}95 \% \\
\text { Confidence } \\
\text { Interval } \\
\end{array}$} & \multirow{2}{*}{$\begin{array}{l}\text { Indirect } \\
\text { Total } \\
\text { Effect } \\
\text { (t-value) }\end{array}$} & \multirow[t]{2}{*}{$p$-value ${ }^{\mathrm{a}}$} & \multirow[t]{2}{*}{ Supported } \\
\hline & & Lower & Upper & & & \\
\hline H6a & $\begin{array}{l}\text { Assurance Statements } \rightarrow \text { Purchase } \\
\text { Intention-Mediated by Consumers } \\
\text { Concerns }\end{array}$ & 0.276 & 0.485 & $\begin{array}{l}0.485 \\
(9.46)\end{array}$ & $<0.001$ & Yes \\
\hline H6b & $\begin{array}{l}\text { Assurance Seals } \rightarrow \text { Purchase Intention- } \\
\text { Mediated by Consumers Concerns }\end{array}$ & 0.208 & 0.362 & $\begin{array}{l}0.355 \\
(7.18)\end{array}$ & $<0.001$ & Yes \\
\hline
\end{tabular}

\subsection{Post-hoc Analysis}

To make sure that our research design and analysis had enough power to find the significant relationships for all the dependent variables in this study, we applied the power analysis method for multiple regression suggested by Cohen [88] and Cohen, Cohen, West and Aiken [89]. The results of the power analysis show that the calculated powers of all the dependent variables is more than .95 . Therefore, statistical power of our analysis is not an issue in this study.

To examine whether the two assurance mechanisms complement or substitute each other, this study examines the interaction effects of assurance seals and assurance statements on the three consumer concerns. We applied the method suggested by Chin, Marcolin and Newsted [90] to examine the interaction effects using Smart PLS. The analysis results (See Table 7) reveal that the interaction effect of assurance seals and assurance statements on privacy concerns and product and service concerns are significant $(p<0.001)$. In contrast, the interaction effect of the two assurance mechanisms on transaction security concerns is not significant $(p>0.05)$. This finding suggests that the two mechanisms studied in 
this work complement each other in such a way that when one mechanism is available the effect of the other one on consumer concerns will increase.

Table 7. Test Results for Interaction Effect of Assurance Mechanisms on Consumer Concerns

\begin{tabular}{|l|c|}
\hline Relationship & Coefficient \\
\hline Assurance Statements $\times$ Assurance Seals $\rightarrow$ Privacy Concerns & $-0.246^{* * *}$ \\
\hline Assurance Statements $\times$ Assurance Seals $\rightarrow$ Product \& Service Concerns & $-0.207 * * *$ \\
\hline Assurance Statements $\times$ Assurance Seals $\rightarrow$ Transaction Security Concerns & $-0.108^{\mathrm{NS}}$ \\
\hline Note. ${ }^{* * *} p<0.001,{ }^{\text {NS }}$ Non-significant & \\
\hline
\end{tabular}

\section{Discussion}

The results show that privacy concern and security concern are important to online consumers as they relate to consumers' purchase intention; assurance seals and assurance statements are important remedies for these two concerns. Unlike our expectation, the effect of product and service concern on purchase intention is not significant. This finding contradicts previous studies [e.g., 6, 91] that have posited a significant negative effect of online consumers' concern on their purchase decision. One possible explanation for this contradiction is that most of our respondents chose popular online shopping websites such as Amazon and eBay and, therefore, did not have much concern with product and service risks. The great wealth of consumer data in these major websites is likely to attract cyber criminals around the globe and, hence, subject the sites to more transaction security issues. Meanwhile, the large accumulation of consumer data on these sites may also entice vendors to monetarize consumer privacy for profits. Therefore, privacy concern and transaction security concern still represent valid concerns for consumers who visit these shopping websites.

In addition, we test the mediating role of consumer concerns using Preacher-Hayes mediation test method and the results confirmed the mediating effect of consumers' concerns. Another interesting finding is that third-party assurance seals negatively relate to one's transaction security concerns whereas assurance statements negatively relate to all three concerns. Compared with third-party assurance seals which cast a total effect of $0.12(-0.254 *-0.473)$, assurance statements have a greater total effect of $0.31(-$ 
$0.436 \times-0.145+-0.524 \times-0.473)$ on consumers' purchase intention. This suggests that online vendors may opt for more self-reliance (i.e., own assurance statements) than seeking external assistance (i.e., third-party assurance seals) in mitigating consumer concerns.

In summary, online consumer purchase intention is affected by consumer's concerns regarding privacy and transaction security in e-commerce websites. Online shopping websites could increase consumers' purchase intentions by decreasing these concerns through the use of assurance mechanisms in their websites. The interaction effect of assurance statements and seals on privacy concerns and product and service concerns are significant; this result suggests that the two mechanisms studied in this work can be complement of each other in such a way that when one mechanism is available the effect of the other one on consumer concerns will increase.

Like any other studies, this study has a number of limitations. The first limitation of our study is that we used university students as our sample frame. Some researchers argue that a student sample lacks external validity [92], though there are a number of studies in the context of e-commerce that used students as their sample frame [e.g., 37, 93, 94]. Another limitation of our study is that our research model only focused on the effect of consumers concerns on purchase intention. The reason for this is because the primary focus of our research was in finding the effect of assurance mechanisms on purchase intention. According to the Valance framework by Peter and Tarpey Sr [49], consumers used three factors to product purchase decisions: (1) minimizing perceived risk, (2) maximizing perceived return or benefit, and (3) maximizing net benefit which is defined as the difference between perceived benefit and risk. Thus, lack of consideration of benefit in our research model could be one limitation for our research that could be addressed by future studies. The third limitation of our research is that we did not consider personal factors such as risk aversion discussed by Donthu and Garcia [95] in our model. For the sake of parsimony, we focus on consumers' concerns in our research while avoiding the involvement of other factors discussed by previous researchers [e.g., 36]. 


\section{Theoretical contributions}

The study contributes to literature in several ways. Firstly, our study categorizes online consumers' concerns and empirically tests the relationship between these concerns and consumers' purchase intention. In line with procedural fairness theory, our research model underscores the value of web assurance mechanisms in mitigating consumers' concerns. Previous researches in this context suggested that popular assurance mechanisms affect consumers' purchase intention by influencing consumers' trust [e.g., 8, 96]. In this paper, we posit consumers' concerns instead of trust as mediators for the effect of web assurance mechanisms. We suggest that web assurance mechanisms on the website negatively affect concerns that consumers have in their online shopping experience so that purchasing decisions can be made easier. That is why we believe that consumer concerns play more important role in this situation. Post hoc analysis further shows the two assurance mechanisms complement each other in affecting consumer concerns.

Second, we empirically confirm that online consumers' concerns mediate the effect of assurance statements and assurance seals on purchase intention. These findings contribute to the existing literature by supporting that consumers' concerns should be considered as an important mediation for purchase intention, which has been omitted as consideration in previous studies. Future researchers could apply our research model to different contexts such as mobile commerce in order to further examine the importance of consumers concerns.

Third, we find product and service concern as an insignificant predictor for consumers' purchase intention. This is an interesting finding because it is not consistent with the result of other studies [e.g., 6, 91]. This contradictory finding may show that online consumers are not much concerned about the products and services that provided by the online vendors; they are more concerned about fraudulent behaviors of the online vendors including misuse of their personal information and transaction related information [97]. Interestingly, this finding suggests the differentiating importance of the three concerns. That is, consumer concerns on security and privacy are deemed more important than concern on product 
and services (a non-information security related concern), when the three are jointly considered by online consumers. Findings as such as new to the literature on consumer concerns as they underscore security and privacy as pronounced threats to online users.

\section{Practical implications}

From practical perspective, this study has a number of implications. First, our study's results show that an assurance seal does not have any effect on a consumers' perceived privacy and product and service concerns. One possible explanation is that the online shopping websites have not communicated the assurance seals' values to the consumers appropriately. Because of a lack of communication consumers are not able to understand the value of the assurance seal. In response to this finding, vendors of online stores may provide educational materials that help consumers uncover the true meanings of assurance seals. Doing such may help leverage more benefits of assurance seals as one effective assurance mechanism.

Second, the study stresses the effect of privacy and transaction security concerns on consumers' purchase intention and explains this effect by using assurance mechanisms, online vendors could decrease these concerns and increase their sale and profitability. Therefore, this could be an important implication for practitioners to decrease their consumers concerns. For the least, vendors may prioritize their resources on these two assurance mechanisms. Finally, although assurance seals negatively affect consumers' privacy concerns, assurance statements affect all the three categories of concerns discussed in this study. Thus e-commerce websites may benefit from this finding by improving the assurance statements that they use on their website to decrease their consumers' concerns more than before.

\section{Conclusion}

Although, there has been a rapid growth in the e-commerce growth in the recent years, online consumers still have different concerns whenever they interact with these websites. Web assurance mechanism are one of the information assurance measures that e-commerce websites use to affect these concerns. 
Applying procedural fairness theory, this study examines how web assurance mechanisms influence consumers' purchase intention by affecting their privacy, transaction security, and product and services concerns. Whereas assurance seals only affect consumers' transaction security concerns, web assurance statements affect all the three concerns of consumers in the research model. This finding reveals that online consumers' web assurance statements are a more effective mechanism than assurance seals in the e-commerce context. Moreover, we find the two assurance mechanisms complement each other in mitigating consumer concerns. In addition, this work's findings show that consumers' purchase intention is only affected by privacy and security concerns, but not non-information security concerns such as the product/service concern. Finally, we find that online consumers' concerns mediate the effect of the two assurance mechanism on consumers purchase intention.

\section{Acknowledgement}

The research of second and third authors have been supported by the National Science Foundation under grant number 1241768 and grant numbers 1554480 , respectively. The usual disclaimer applies.

\section{References}

[1] R. DeNale, X. Liu, D. Weidenhamer, Quarterly Retail E-Commerce Sales 2nd Quarter 2015, in: D.o. Commerce (Ed.), Washington, D.C., 2015.

[2] A. Bhaiya, E-Commerce Sales Sweep the Globe: Here's How to Get in the Swing, HuffingtonPost.com, 2015.

[3] Y.-H. Chen, I. Hsu, C.-C. Lin, Website attributes that increase consumer purchase intention: A conjoint analysis, Journal of Business Research, 63 (2010) 1007-1014.

[4] S.A. Eroglu, K.A. Machleit, L.M. Davis, Atmospheric qualities of online retailing: a conceptual model and implications, Journal of Business Research, 54 (2001) 177-184.

[5] R. Kalakota, A.B. Whinston, Electronic Commerce: a Manager's Guide., Addison-Wesley Professional,1997.

[6] A.D. Miyazaki, A. Fernandez, Consumer perceptions of privacy and security risks for online shopping, Journal of Consumer Affairs, 35 (2001) 27-44.

[7] D.J. Kim, D.L. Ferrin, H.R. Rao, A Trust-Based Consumer Decision-Making Model in Electronic Commerce: The Role of Trust, Perceived Risk, and their Antecedents, Decision Support Systems, 44 (2008) 544-564. 
[8] K.M. Kimery, M. McCord, Third party assurances: mapping the road to trust in eretailing, Journal of Information Technology Theory and Application (JITTA), 4 (2002) 7.

[9] D.H. McKnight, C.J. Kacmar, V. Choudhury, Shifting Factors and the Ineffectiveness of Third Party Assurance Seals: A Two-Stage Model of Initial Trust in a Web Business, Electronic Markets, 14 (2004) 252-266.

[10] H. Zhang, Trust promoting seals in electronic markets: impact on online shopping decisions, Journal of Information Technology Theory and Application (JITTA), 6 (2005) 5.

[11] K. Kimery, M. McCord, Third-Party Assurances: Mapping the Road to Trust in E-Retailing, Journal of Information Technology Theory and Application, 4 (2002) 63-83.

[12] W.V. Maconachy, C.D. Schou, D. Ragsdale, D. Welch, A model for information assurance: An integrated approach, Proceedings of the 2001 IEEE Workshop on Information Assurance and Security, New York, USA, 2001.

[13] M. Arcand, J. Nantel, M. Arles-Dufour, A. Vincent, The impact of reading a web site's privacy statement on perceived control over privacy and perceived trust, Online Information Review, 31 (2007) 661-681.

[14] G. Bansal, F.M. Zahedi, D. Gefen, Efficacy of Privacy Assurance Mechanisms in the Context of Disclosing Health Information Online, AMCIS 2008 Proceedings, 2008, pp. 178.

[15] D. Kim, N. Sivasailam, H.R. Rao, Information Assurance in B2C Websites for Information Goods/Services, Electronic Markets, 14 (2004) 344-359.

[16] H.R. Nemati, T.V. Dyke, Do Privacy Statements Really Work/, International Journal of Information Security and Privacy, 3 (2009) 45-64.

[17] C. Gauzente, Web Merchants' Privacy and Security Statements, Journal of Electronic Commerce Research, 5 (2004) 181-198.

[18] X. Hu, G. Wu, Y. Wu, H. Zhang, The Effects of Web Assurance Seals on Consumers' Initial Trust in an Online Vendor, Decision Support Systems, 48 (2010) 407-418.

[19] D. Kim, Self-Perpcetion-Based Versus Transference-Based Trust Determinants in ComputerMediated Transactions, Journal of Management Information Systems, 24 (2008) 13-45.

[20] H. Zhang, Trust-Promoting Seals in Electronic Markets, Journal of Information Technology Theory and Applicatio, 6 (2005) 29-40.

[21] I. Park, A. Bhatnagar, H.R. Rao, Assurance Seals, On-Line Customer Satisfaction, and Repurchase Intention, International Journal of Electronic Commerce, 14 (2010) 11-34.

[22] G. Bansal, F. Zahedi, D. Gefen, The Role of Privacy Assurance Mechanisms in Building Trust and the Moderating Role of Privacy Concern, European Journal of Information Systems, 24 (2015) 1-21.

[23] F. Belanger, J.S. Hiller, W.J. Smith, Trustworthiness in Electronic Commerce: The Role of Privacy, Security, and Site Attributes, Journal of Strategic Information Systems, 11 (2002) 245-270.

[24] D.J. Kim, C. Steinfield, Y.-J. Lai, Revisiting the role of web assurance seals in business-to-consumer electronic commerce, Decision Support Systems, 44 (2008) 1000-1015.

[25] X. Hu, G. Wu, Y. Wu, H. Zhang, 2005, 2005.

[26] T.-Z. Chang, A.R. Wildt, Price, product information, and purchase intention: An empirical study, Journal of the Academy of Marketing Science, 22 (1994) 16-27.

[27] M. Brown, N. Pope, K. Voges, Buying or browsing?: An exploration of shopping orientations and online purchase intention, European Journal of Marketing, 37 (2003) 1666-1684. 
[28] B. Bai, R. Law, I. Wen, The impact of website quality on customer satisfaction and purchase intentions: Evidence from Chinese online visitors, International Journal of Hospitality Management, 27 (2008) 391-402.

[29] I. Qureshi, Y. Fang, E. Ramsey, P. McCole, P. Ibbotson, D. Compeau, Understanding online customer repurchasing intention and the mediating role of trust--an empirical investigation in two developed countries, European Journal of Information Systems, 18 (2009) 205-222.

[30] A. Poddar, N. Donthu, Y. Wei, Web site customer orientations, Web site quality, and purchase intentions: The role of Web site personality, Journal of Business Research, 62 (2009) 441-450.

[31] J. Park, S.J. Lennon, L. Stoel, On-line product presentation: Effects on mood, perceived risk, and purchase intention, Psychology \& Marketing, 22 (2005) 695-719.

[32] S. Otim, V. Grover, An empirical study on web-based services and customer loyalty, European Journal of Information Systems, 15 (2006) 527-541.

[33] M. Al Kailani, R. Kumar, Investigating uncertainty avoidance and perceived risk for impacting internet buying: a study in three national cultures, International Journal of Business and Management, 6 (2011) p76.

[34] A. Bhatnagar, S. Misra, H.R. Rao, On Risk, Convenience, and Internet Shopping Behavior, Communications of the ACM, 43 (2000) 98-105.

[35] S.M. Forsythe, B. Shi, Consumer Partronage and Risk Perceptions in Internet Shopping, Journal of Business Research, 56 (2003) 867-875.

[36] M.K. Chang, W. Cheung, V.S. Lai, Literature derived reference models for the adoption of online shopping, Information \& Management, 42 (2005) 543-559.

[37] F. Belanger, J.S. Hiller, W.J. Smith, Trustworthiness in electronic commerce: the role of privacy, security, and site attributes, The Journal of Strategic Information Systems, 11 (2002) 245-270.

[38] P.B. Lowry, J. Cao, A. Everard, Privacy concerns versus desire for interpersonal awareness in driving the use of self-disclosure technologies: The case of instant messaging in two cultures, Journal of Management Information Systems, 27 (2011) 163-200.

[39] C. Flavián, M. Guinalíu, Consumer trust, perceived security and privacy policy: three basic elements of loyalty to a web site, Industrial Management \& Data Systems, 106 (2006) 601-620.

[40] T. Dinev, H. Xu, J.H. Smith, P. Hart, Information privacy and correlates: an empirical attempt to bridge and distinguish privacy-related concepts, European Journal of Information Systems, 22 (2013) 295-316.

[41] H.J. Smith, T. Dinev, H. Xu, Information privacy research: an interdisciplinary review, MIS quarterly, 35 (2011) 989-1016.

[42] S.M. Furnell, T. Karweni, Security implications of electronic commerce: a survey of consumers and businesses, Internet Research, 9 (1999) 372-382.

[43] W.D. Salisbury, R.A. Pearson, A.W. Pearson, D.W. Miller, Perceived security and World Wide Web purchase intention, Industrial Management \& Data Systems, 101 (2001) 165-177.

[44] C. Ranganathan, S. Ganapathy, Key dimensions of business-to-consumer web sites, Information \& Management, 39 (2002) 457-465.

[45] J. Lazzarotti, Report Says Russian Hackers Stole 1.2 Billion Usernames and Passwords, But Don't Let "Breach Fatigue" Take Hold, Workplace Privacy, Data Management \& Security Report, Jackson Lewis P.C., White Plains, NY, 2014. 
[46] L.V. Casaló, C. Flavián, M. Guinalíu, The role of security, privacy, usability and reputation in the development of online banking, Online Information Review, 31 (2007) 583-603.

[47] C. Van Slyke, J.T. Shim, R. Johnson, J. Jiang, Concern for information privacy and online consumer purchasing, Journal of the Association for Information Systems, 7 (2006) 415-444.

[48] H. Van der Heijden, T. Verhagen, M. Creemers, Understanding online purchase intentions: contributions from technology and trust perspectives, European Journal of Information Systems, 12 (2003) 41-48.

[49] J.P. Peter, L.X. Tarpey Sr, A comparative analysis of three consumer decision strategies, Journal of consumer research, 2 (1975) 29-37.

[50] G.R. Milne, M.E. Gordon, Direct mail privacy-efficiency trade-offs within an implied social contract framework, Journal of Public Policy \& Marketing, 12 (1993) 206-215.

[51] E.F. Stone, D.L. Stone, Privacy in organizations: Theoretical issues, research findings, and protection mechanisms, Research in personnel and human resources management, 8 (1990) 349-411.

[52] M.J. Culnan, P.K. Armstrong, Information privacy concerns, procedural fairness, and impersonal trust: An empirical investigation, Organization Science, 10 (1999) 104-115.

[53] Y. Li, Theories in online information privacy research: A critical review and an integrated framework, Decision Support Systems, 54 (2012) 471-481.

[54] K.-L. Hui, H.H. Teo, S.-Y.T. Lee, The value of privacy assurance: an exploratory field experiment, Mis Quarterly, 31 (2007) 19-33.

[55] V. Lala, V. Arnold, S.G. Sutton, L. Guan, The impact of relative information quality of e-commerce assurance seals on Internet purchasing behavior, International Journal of Accounting Information Systems, 3 (2002) 237-253.

[56] G.R. Milne, M.J. Culnan, Using the content of online privacy notices to inform public policy: A longitudinal analysis of the 1998-2001 US web surveys, The Information Society, 18 (2002) 345-359.

[57] G.R. Milne, M.J. Culnan, Strategies for reducing online privacy risks: Why consumers read (or don't read) online privacy notices, Journal of Interactive Marketing, 18 (2004) 15-29.

[58] A.F. Westin, Special report: legal safeguards to insure privacy in a computer society, Communications of the ACM, 10 (1967) 533-537.

[59] P. Ratnasingham, Internet-based EDI trust and security, Information Management \& Computer Security, 6 (1998) 33-39.

[60] M.S. Ackerman, L.F. Cranor, J. Reagle, Privacy in e-commerce: examining user scenarios and privacy preferences, Proceedings of the 1st ACM conference on Electronic commerce, ACM, 1999, pp. $1-8$.

[61] E. Singer, H.-J. Hippler, N. Schwarz, Confidentiality assurances in surveys: Reassurance or threat?, International Journal of Public Opinion Research, 4 (1992) 256-268.

[62] H. Xu, H.-H. Teo, B.C.Y. Tan, Predicting the Adoption of Location-Based Services: The Role of Trust and Perceived Privacy Risk., ICIS, Las Vegas, Nevada, 2005.

[63] B.L. Delgado-Márquez, N.E. Hurtado-Torres, J.A. Aragón-Correa, On the Measurement of Interpersonal Trust Transfer: Proposal of Indexes, Social Indicators Research, 113 (2013) 433-449.

[64] Y. Lu, S. Yang, P.Y.K. Chaung, Y. Cao, Dynamics between the Trust Transfer Process and Intention to Use Mobile Payment Services: A Cross Environment Perspective, Information \& Management, 48 (2011) 393-403. 
[65] K.J. Stewart, Trust Transfer on the World Wide Web, Organization Science, 14 (2003) 5-17.

[66] WebTrust, Overview of Trust Services, CPA Canada, Toronto, Canada, 2015.

[67] TRUSTe, Privacy Assessments \& Certifications, EMEA, London, UK, 2015.

[68] R.K. Chellappa, P.A. Pavlou, Perceived information security, financial liability and consumer trust in electronic commerce transactions, Logistics Information Management, 15 (2002) 358-368.

[69] A. Miyazaki, S. Krishnamurthy, Internet Seals of Approval: Effects on Online Privacy Policies and Consumer Perceptions, Journal of Consumer Affairs, 36 (2002) 28-49.

[70] R. Chen, S.K. Sharma, Learning and self-disclosure behavior on social networking sites: the case of Facebook users, European Journal of Information Systems, 24 (2015) 93-106.

[71] R. Wakefield, The influence of user affect in online information disclosure, The Journal of Strategic Information Systems, 22 (2013) 157-174.

[72] D. Barclay, C. Higgins, R. Thompson, The partial least squares (PLS) approach to causal modeling: personal computer adoption and use as an illustration, Technology studies, 2 (1995) 285-309.

[73] J. Henseler, C.M. Ringle, R.R. Sinkovics, The Use of PLS Path Modeling in International Marketing, Advances in International Marketing, 20 (2009) 277-319.

[74] J. Hulland, Use of partial least squares (PLS) in strategic management research: a review of four recent studies, Strategic management journal, 20 (1999) 195-204.

[75] J.F. Hair Jr, R.E. Anderson, R.L. Tatham, B. William C, Multivariate data analysis with readings, Prentice Hall, New Jersy, 1995.

[76] C. Nunnally, H. Bernstein, Psychometric theory, New York: McGraw-Hill, 1978.

[77] C. Fornell, D.F. Larcker, Evaluating structural equation models with unobservable variables and measurement error, Journal of marketing research, 18 (1981) 39-50.

[78] D.-G. Ko, L.J. Kirsch, W.R. King, Antecedents of knowledge transfer from consultants to clients in enterprise system implementations, MIS quarterly, 29 (2005) 59-85.

[79] P.M. Podsakoff, S.B. MacKenzie, J.-Y. Lee, N.P. Podsakoff, Common method biases in behavioral research: A critical review of the literature and recommended remedies, Journal of Applied Psychology, 88 (2003) 879-903.

[80] D.T. Campbell, D.W. Fiske, Convergent and discriminant validation by the multitrait-multimethod matrix, Psychological bulletin, 56 (1959) 81-105.

[81] H. Liang, N. Saraf, Q. Hu, Y. Xue, Assimilation of enterprise systems: the effect of institutional pressures and the mediating role of top management, MIS quarterly, 31 (2007) 59-87.

[82] X. Zhao, J.G. Lynch, Q. Chen, Reconsidering Baron and Kenny: Myths and truths about mediation analysis, Journal of consumer research, 37 (2010) 197-206.

[83] R.M. Baron, D.A. Kenny, The moderator-mediator variable distinction in social psychological research: Conceptual, strategic, and statistical considerations, Journal of personality and social psychology, 51 (1986) 1173-1182.

[84] K.J. Preacher, A.F. Hayes, SPSS and SAS procedures for estimating indirect effects in simple mediation models, Behavior research methods, instruments, \& computers, 36 (2004) 717-731.

[85] D.P. MacKinnon, C.M. Lockwood, J. Williams, Confidence limits for the indirect effect: Distribution of the product and resampling methods, Multivariate behavioral research, 39 (2004) 99-128. 
[86] A.F. Hayes, Introduction to mediation, moderation, and conditional process analysis: A regressionbased approach, Guilford Press2013.

[87] K.J. Preacher, A.F. Hayes, Asymptotic and resampling strategies for assessing and comparing indirect effects in multiple mediator models, Behavior research methods, 40 (2008) 879-891.

[88] J. Cohen, Statistical Power Analysis for the Behavioral Sciences. 2nd edn. Hillsdale, New Jersey: L, Erlbaum, 1988.

[89] J. Cohen, P. Cohen, S.G. West, L.S. Aiken, Applied multiple regression/correlation analysis for the behavioral sciences, Routledge2013.

[90] W.W. Chin, B.L. Marcolin, P.R. Newsted, A partial least squares latent variable modeling approach for measuring interaction effects: Results from a Monte Carlo simulation study and an electronic-mail emotion/adoption study, Information systems research, 14 (2003) 189-217.

[91] R.A. Spreng, G.D. Harrell, R.D. Mackoy, Service recovery: impact on satisfaction and intentions, Journal of Services Marketing, 9 (1995) 15-23.

[92] M.E. Gordon, L.A. Slade, N. Schmitt, The" science of the sophomore" revisited: From conjecture to empiricism, Academy of management review, 11 (1986) 191-207.

[93] P.A. Pavlou, Consumer acceptance of electronic commerce: integrating trust and risk with the technology acceptance model, International journal of electronic commerce, 7 (2003) 101-134.

[94] M.M. Yenisey, A.A. Ozok, G. Salvendy, Perceived security determinants in e-commerce among Turkish university students, Behaviour \& Information Technology, 24 (2005) 259-274.

[95] N. Donthu, A. Garcia, The internet shopper, Journal of advertising research, 39 (1999) 52-58.

[96] D.H. McKnight, V. Choudhury, C. Kacmar, Trust in e-commerce vendors: a two-stage model, Proceedings of the twenty first international conference on Information systems, 2000, pp. 532-536.

[97] N. Olivero, P. Lunt, Privacy versus willingness to disclose in e-commerce exchanges: The effect of risk awareness on the relative role of trust and control, Journal of Economic Psychology, 25 (2004) 243262.

[98] H. Xu, T. Dinev, J. Smith, P. Hart, Information Privacy Concerns: Linking Individual Perceptions with Institutional Privacy Assurances., Journal of the Association for Information Systems, 12 (2011) 798-824.

[99] S.M. Lee, J. Choi, S.-G. Lee, The impact of a third-party assurance seal in customer purchasing intention, Journal of Internet commerce, 3 (2004) 33-51.

[100] M.-S. Chen, J. Han, P.S. Yu, Data mining: an overview from a database perspective, Knowledge and data Engineering, IEEE Transactions on, 8 (1996) 866-883.

[101] D. Gefen, E-commerce: the role of familiarity and trust, Omega, 28 (2000) 725-737.

[102] S.L. Jarvenpaa, N. Tractinsky, L. Saarinen, Consumer trust in an Internet store: A cross-cultural validation, Journal of Computer-Mediated Communication, 5 (1999). 